\title{
Empowering Speaking Achievement by Using Inside-Outside Fishbowl
}

\author{
Ridha IIma ${ }^{1}$ and Jenny Elvinna Manurung ${ }^{2}$ \\ 1,2 Universitas Tridinanti Palembang \\ 1idhailma@univ-tridinanti.ac.id
}

\begin{abstract}
This study aimed to describe the implication of speaking achievement by applying inside-outside fishbowl (IOF) to the students of Tridinanti University Palembang. The total number of samples was seventeen of sixth-semester students of the English study program of Tridinanti University Palembang, they were selected by using purposive sampling. This study used classroom action research. It consisted of two cycles; cycle I and cycle II. Speaking tests and observations were used to collect the data. It was found that there was a significant improvement in students' speaking achievement, the mean score of speaking achievement in cycle I was 64.47 , and there was only $29.41 \%$ of the students who achieved predetermined minimum standard mastery. Based on the finding on cycle I, the writers needed to improve the students' speaking achievement by conducting cycle II. After did cycle II, the mean score of speaking achievement was 79.76 , and there was $94.11 \%$ of the students who achieved predetermined minimum standard mastery. This strategy builds the students' participation in doing discussion and helps them reflect on what a good discussion looks like. Using Inside-Outside Fishbowl (IOF) in EFL classrooms has helped both lecturers and learners in many different ways. It has a positive impact on both of them. Regarding students, IOF application in the classroom has helped them to think and organize their thoughts. As a result, they have started to manage their learning and to gain a sense of responsibility. Moreover, they have shown readiness to speak in the target language with more confidence and fluency. Students have begun to have opportunities so they can show how good they are in speaking and sharing ideas.
\end{abstract}

Keywords: empowering, inside-outside fishbowl, speaking achievement

\section{INTRODUCTION}

Speaking is one of the important skills that should be mastered by students all over the world. By having this skill they can perform their competence in English for instance the students can share their knowledge, value, and attitude to others through oral speaking. Therefore, those competencies can be applied in real-life through oral communication. The reason for choosing speaking as the core of the research is the necessity of speaking which is more than other skills in daily life. According to Bahar (2013), most English learners regard English speaking ability as the measure of mastering English. How good their English depends on how fluent they speak. From that statement, the teacher will detect their students speaking ability based on the effective method in the teaching process. Moreover, Bahar (2013) also stated that many research reports show that people use speaking for a variety of different purposes, such as, to make social contact with a people, to establish rapport (understanding), to build a social relationship. Therefore, English students need to recognize speaking is not only a classroom subject, but also it is a matter of producing language appropriately according to the functional and social convention.

Since speaking is very crucial to learn, many English learners in the world study are to develop proficiency in that skill (Richard and Rodger, 2001). Speaking becomes one of the compulsory subjects that should be taken and comprehended by students of the English Study Program to enable them to communicate with others orally. Besides, the students of the English Study Program should master speaking to transfer their knowledge and information to their next students since after they have graduated from their university, they would be a teacher. Grugeon and Dawes (2005) claimed 
that the importance of teaching speaking stems from the fact that human beings have been acquiring a language through that skill long before they began reading and writing. Besides, the students of a second and foreign language are considered successful if they can communicate effectively in the target language (Nunan, 2004).

Indonesian learners commonly had not attained a good level of oral proficiency. Some scholars showed this problem, for example. Many teachers and educators view English teaching as a neutral practice. However, teaching English cannot be seen as a neutral practice given the cultural and political assumptions embedded in it (Liando, 2009: 146). Then, Kusmaryanti (2009) found out that students have a great number of errors in speaking such as pronunciation, grammatical accuracy, vocabulary, fluency, and interactive communication. Also, Tutyandary (2005) stated that some of the students kept silent in speaking class and it happened because of the pressure of speaking tasks that require them to present individually and spontaneously in limited time. She mentioned that the students kept silent because of a lack of self-confidence, motivation, learning interest, prior knowledge, and poor teacher-learner relationship.

Besides, the English proficiency index refers to a report of which attempts to rank countries by the average level of English skills among adults (EF EPI, 2015: 4). Based on the data of English Proficiency Index (2015) which ranked the proficiency of English among a broad population in 70 countries and territories, Indonesia was in the rank of 33 with score 52.91 below Japan and Taiwan. In other words, Indonesia was still in the very low proficiency category. Indeed, Indonesia as the developing country has to increase its level of English proficiency through a lot of treatments of four skills of English in teaching and learning process as Singapore and Malaysia which were in the rank of 12 and 14 had higher school attendance of their students and asked the students to have a lot of practices in English classes. Mahripah (2013: 288) assumed that the present study set off to address EFL learners' attitudes towards improving their English speaking performance in the EFL context of Indonesia where there are not many opportunities and resources for learners to improve their English speaking compared to other EFL contexts. Moreover, classroom interaction is also necessary and useful as an educational strategy to enhance speaking skills. The role of interaction in a classroom context in enhancing speaking skills comes from the understanding of its main types: teacher-learner interaction and learner-learner interaction, where negotiation of meaning and the provision of feedback are highlighted.

To add this pain, based on the preliminary study done by one of the writers, as her experience during teaching speaking class at Tridinanti University Palembang, she did some observations and interviews with the students. She found that most of the students were passive and shy to open their mouths, transfer their knowledge and idea through oral communication. In one class consisting of 20 students, about $15 \%$ of the students who were active and fluent in speaking dominated the teaching and learning process. The other students just listened to the lecturer's explanation, kept noting some words, tried to speak, but having silence was the most activity done in the classroom. The students were not too serious as they thought that the subject was not too important because their mindset was only sitting in the class nicely would make the lecturer gave them a good score. They were unmotivated.

Other factors that influence students in language learning especially in speaking are the size of the class, facilities, and the role of English as a foreign language. Time limitation also becomes the problem having by students in speaking, as until this moment the students have to write down every single word to speak, correct the sentences, practice in their seats and speaking in the classroom. On the other side, the classroom facilities were not completed to support communicative activities; in fact, the facilities are very needed to create a real situation in daily communication using English. Thus, Widiati and Cahyono (2006) suggested the teachers have an important role to foster students' achievement to speak English well. In this case, the teachers should build a good relationship with their students, encourage them to use English more often and facilitate them with the tasks in classroom activities to discuss and share ideas. 
There are many ways to make the speaking class become enjoyable, one of the methods is using a fishbowl strategy. Silberman (1996:110) defines that fishbowl is a discussion format that some students make discussion circle and other students make listeners circle in around of discussion group. Fishbowl is the growing structure discussion method that is very useful for the speaking class (Elizabeth, et al., 2005:145). Based on the above explanations, the writer concludes that the fishbowl method is a way to organize a discussion group that contains inside and outside the circle that is useful in speaking class. Fishbowl was able to make students more active and fluent in delivering their ideas and sharing information with others. Then, it could make the students deliver and comprehend the messages discussed to their friends. Finally, the students enabled them to speak accurately in terms of using appropriate expression/language function, intonation and pronunciation. Since it was a good occasion to speak up freely by considering those terms. This strategy is especially useful when the teacher wants to make sure all students participate in the discussion, when the teacher wants to help students reflect on what a good discussion looks like, and when she needs a structure for discussing controversial or difficult topics. Fishbowls make excellent pre-writing activities, often unearthing questions or ideas that students can explore more deeply in an independent assignment. Hornby (1995: 37) has written that teaching speaking is giving instructions to a person to communicate verbally. This means that the teacher should guide and encourage the students to speak; even though they have a very limited vocabulary to use (Wahyuni, Rosdiana \& Fitriani, 2016). Ur (1996: 120) says that the teacher should make as much as possible of the class time for the activities where students talk. In other words, most of the time allotted to speaking must be used by the students, not by the teacher.

The fishbowl is used to encourage verbal interaction among class members to explore issues and share opinions. Harmer (2001: 272) has stated that Fishbowl is a communicative game used as a teaching technique. This technique can help children learn how to work in a small group (Linse, 2006:. 54). On the other hand, Malvin (1996: 22) has stated that Fishbowl can help students focus on group discussions. Although this technique takes much time, it is a good method to combine large and small groups. Fishbowl is a technique that can be used for many things such as modeling group discussions or any other classroom instructional method. It can also be used to help the students think critically about a topic. The Fishbowl technique is a technique that can be used when discussing topics within large groups. The students are then better able to understand the issues, topics, or problems. They can create interesting ideas from reading texts and to answer questions at the end of the discussion period. From

This is also supported by Kurnia (2015), who used the Fishbowl technique and found that the students were then able to tell a story in front of the class and that their recount skills increased and they were better able to organize their speeches. Syafa'ah (2009) also researched with the same technique and her students greatly improved their speaking skills.

Therefore, the writers would like to find out if using the inside-outside fishbowl technique will affect students' speaking achievement. For this reason, based on all the above description, the writers were interested in conducting the research which discussed empowering speaking achievement by using inside-outside fishbowl to the students of Tridinanti University Palembang.

\section{METHODOLOGY}

This study used Classroom Action Research (CAR), it was done to improve the learning quality in the classroom with the teacher as a researcher so that the teaching-learning process will be better. The research was intended to develop a strategy to solve (CAR) the problems found by the researcher in teaching speaking. Kemmis and McTaggart (1998: 14) have stated that CAR is a reflective method of research conducted by doing certain actions to try to improve and increase the quality of teaching practices in the classroom so that those practices become more professional. In the procedure and implementation of the process, some stages were done in repeated cycles. First, 
planning the action was done based on the analysis of the research findings; the second was the implementation of the action that the researcher did in the learning and teaching process, third was observations made by the researcher to collect data during the activity and fourth was data analysis and reflections to show the results of the action in each cycle. The researcher than revised the plan and continued to the next cycle if the action in each cycle was considered as not being successful enough. However, if the actions met the proposed research criteria, another cycle would not be done. According to Sherry, Purnomo, Saleh, and Jaenudin (2010: 23), each cycle consisted of four phases; planning, implementation, observation, and reflection. This following figure 1 was the cycles of the study:

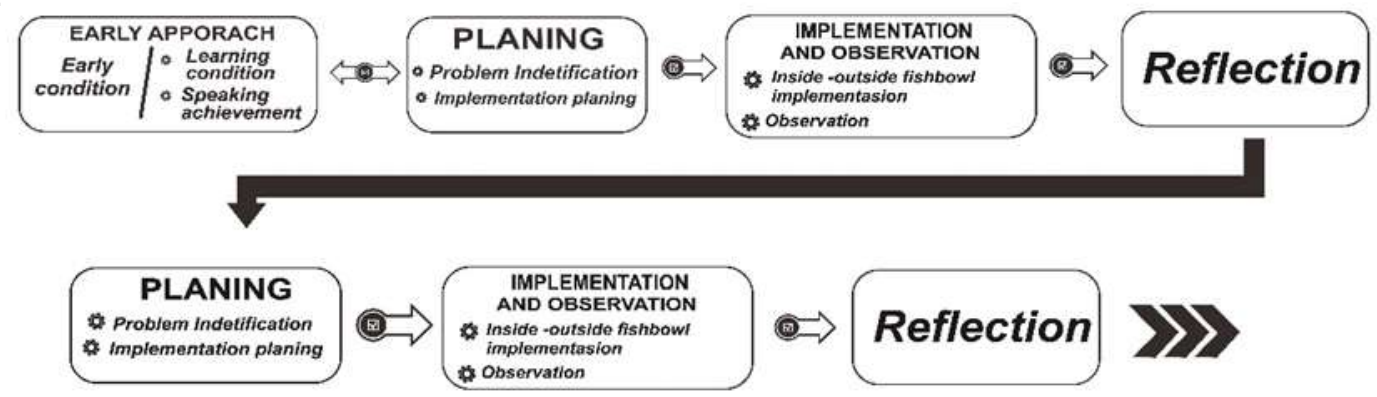

Figure 1 Cycles of the Study

\section{RESULTS AND DISCUSSIONS}

\section{The Result of Speaking Test and Observation in cycle I}

It was found that $70.59 \%$ of the students failed the test, and only $29.41 \%$ of the students enabled to pass the test. In other words, the lecturer had not been successful in delivering the materials yet. Only 5 students who were able to comprehend the materials well. It might be from the teaching strategy, media, materials or situation in the classroom. So, that it needed improvement in those sides to improve students' speaking achievement and achieve the goals of the teaching and learning process, the second cycle was very essential to be done.

According to data analysis, the average score of students speaking achievement was 64.47 in cycle I. The result was in enough categories and it has been reached the target set that is $\geq 71$. At least more than $85 \%$ of students could achieve the score $\geq 71$. The result of the speaking test (progress test in the cycle) I can be seen in chart 1 as follows.

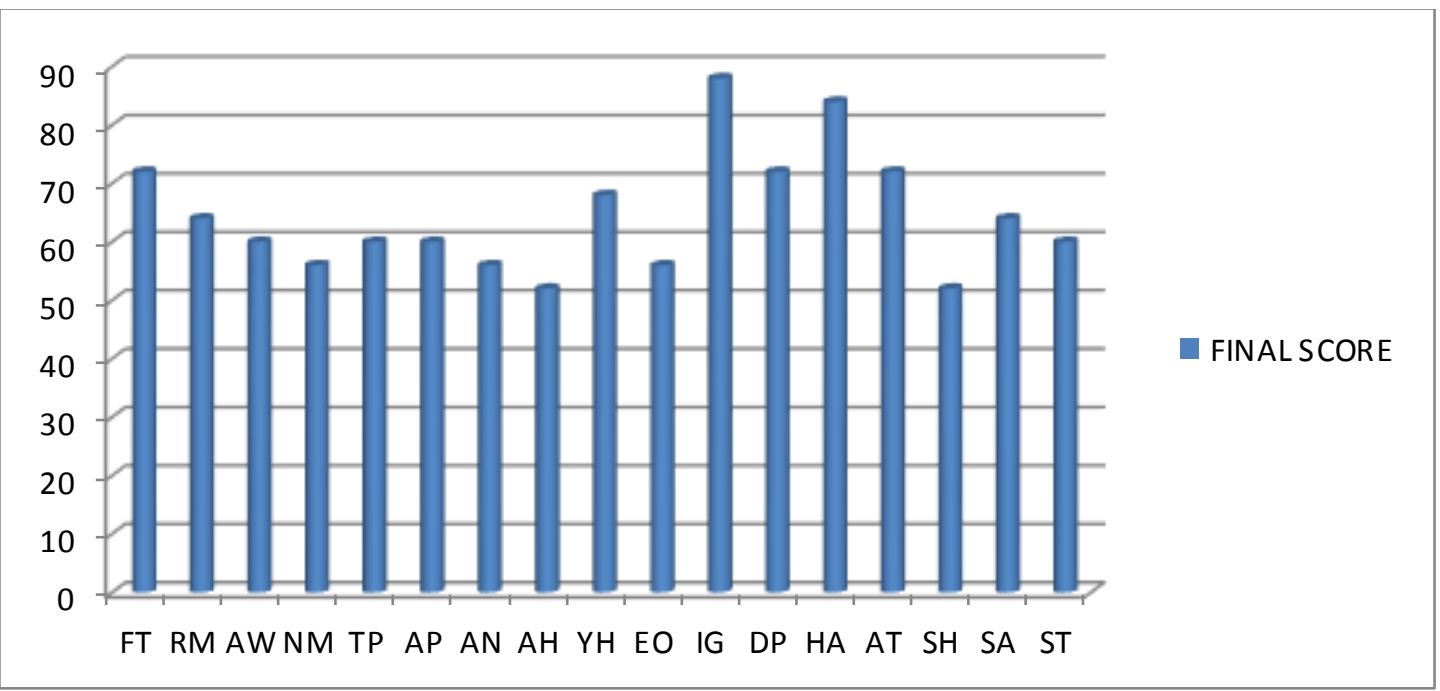

Chart 1 Speaking Test Result in Cycle I 
Furthermore, based on the data analysis of cycle I (students' observation result), it could be concluded that the average score of the test inactivity in a meeting I was 62.76 , meeting II was 66.06 , meeting III was 68.65 and meeting IV was 72.47. The data showed that the students in each meeting could learn to follow the instruction guidelines. At each meeting, the average score increased significantly. The progress rose quite significant but it has been reached the target yet. The complete data can be seen from the chart below (see chart 2).

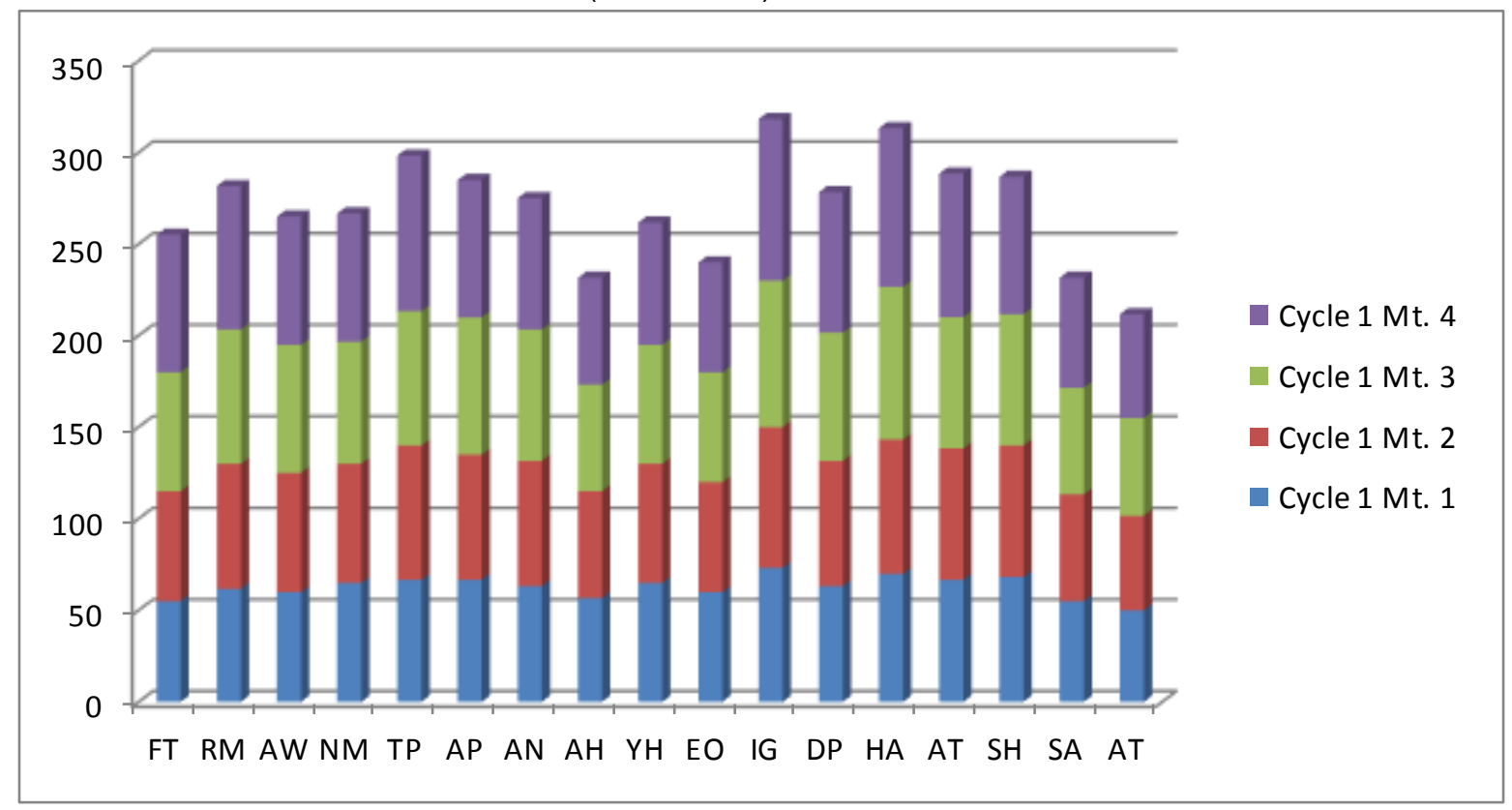

Chart 2 Students' Observation Result in Cycle 1

In other words, the activities which should be improved were the students follow all the guidelines in inside-outside fishbowl treatment and the students were having interaction with each other when discuss occurred.

\section{Reflection of Cycle I}

There were many things which should be improved in the next cycle to enhance students speaking achievement, they are:

1. Cycle II was necessary to be implemented to enhance the students' speaking achievement. The material, media, and teaching strategy were needed to be selected and prepared to gain the goals of the teaching and learning process.

2. The writers could create a teaching and learning situation which was much more fun and enjoyable to attract the students' interest and participation.

3. The average of the score in the test I was 67.47 which was quite far below the standard of completeness. So the researchers should work harder to improve it.

The theme of learning material would be the same, but the various topic would be used. The writers used video and varied pictures to enhance the students' comprehension of the theme and instructions.

\section{Speaking Test Result in Cycle II}

In cycle II, most of the students had good comprehension in following the guidelines of instruction. The progress of students' speaking achievement can be seen in cycle II. The students' speaking achievement rose sharply. The average score gained by the students reached 80.00 . It means all the students passed the speaking test. Their speaking also became fluent. The result of students speaking can be seen in chart 3 below. 


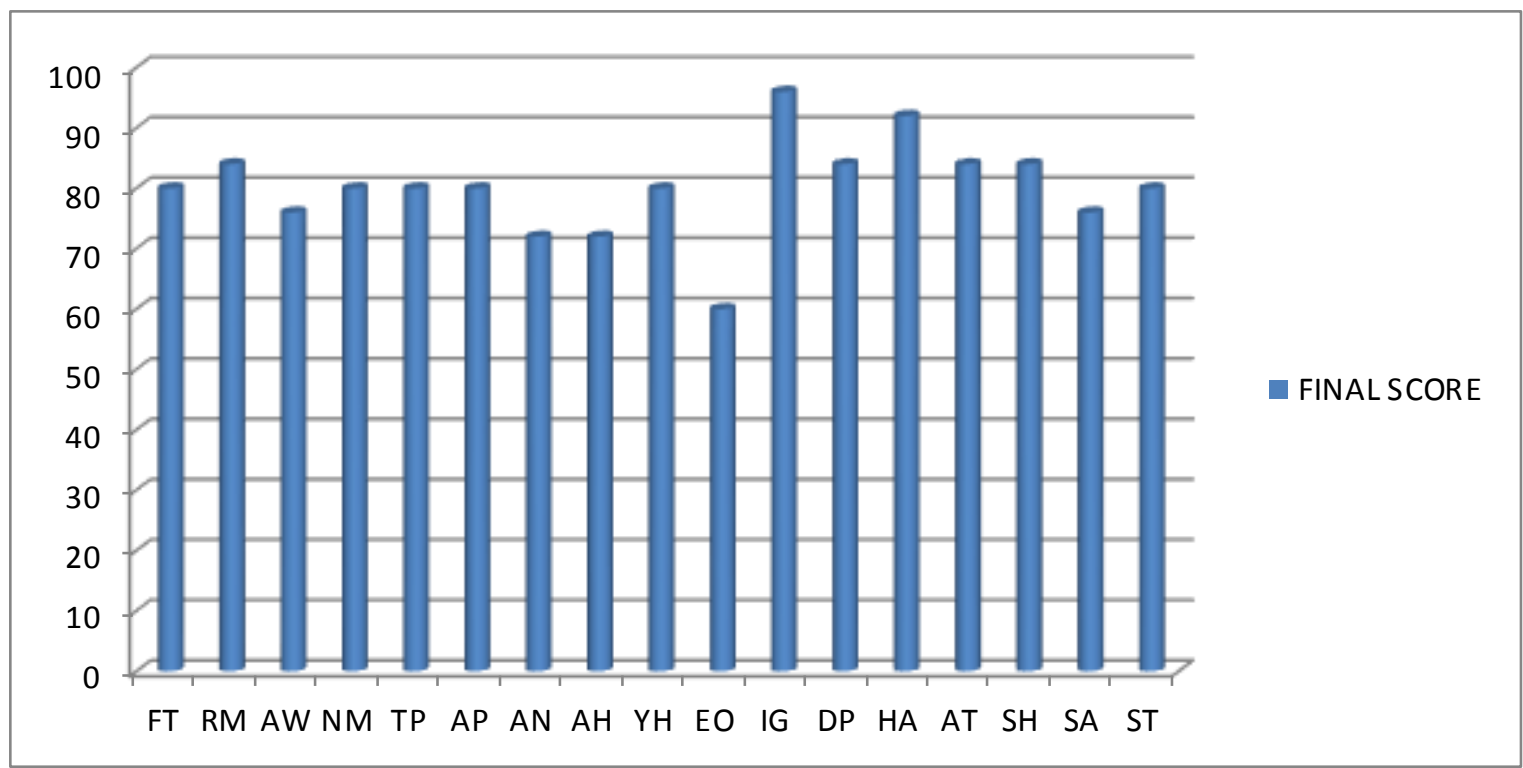

Chart 3 Speaking Test Result in Cycle II

Furthermore, based on the observation result, in cycle II, the average score was 79.10. The data means that the students had followed all the instructions very well. They did all the activities well. The students had no problem in doing the speaking learning activities by using Inside-Outside Fishbowl. The results score proved they could understand and follow those guidelines of instructions.

The data analysis in cycle II in a meeting I was 73.53 , meeting II was 76.88 , meeting III was 80.71 and meeting IV was 84.24 the data showed that the students at each meeting could learn to follow the instruction guidelines. At each meeting, the average score increased significantly. The progress rose very significantly and had reached the target. The result of observation in cycle II can be seen in this chart as follows.

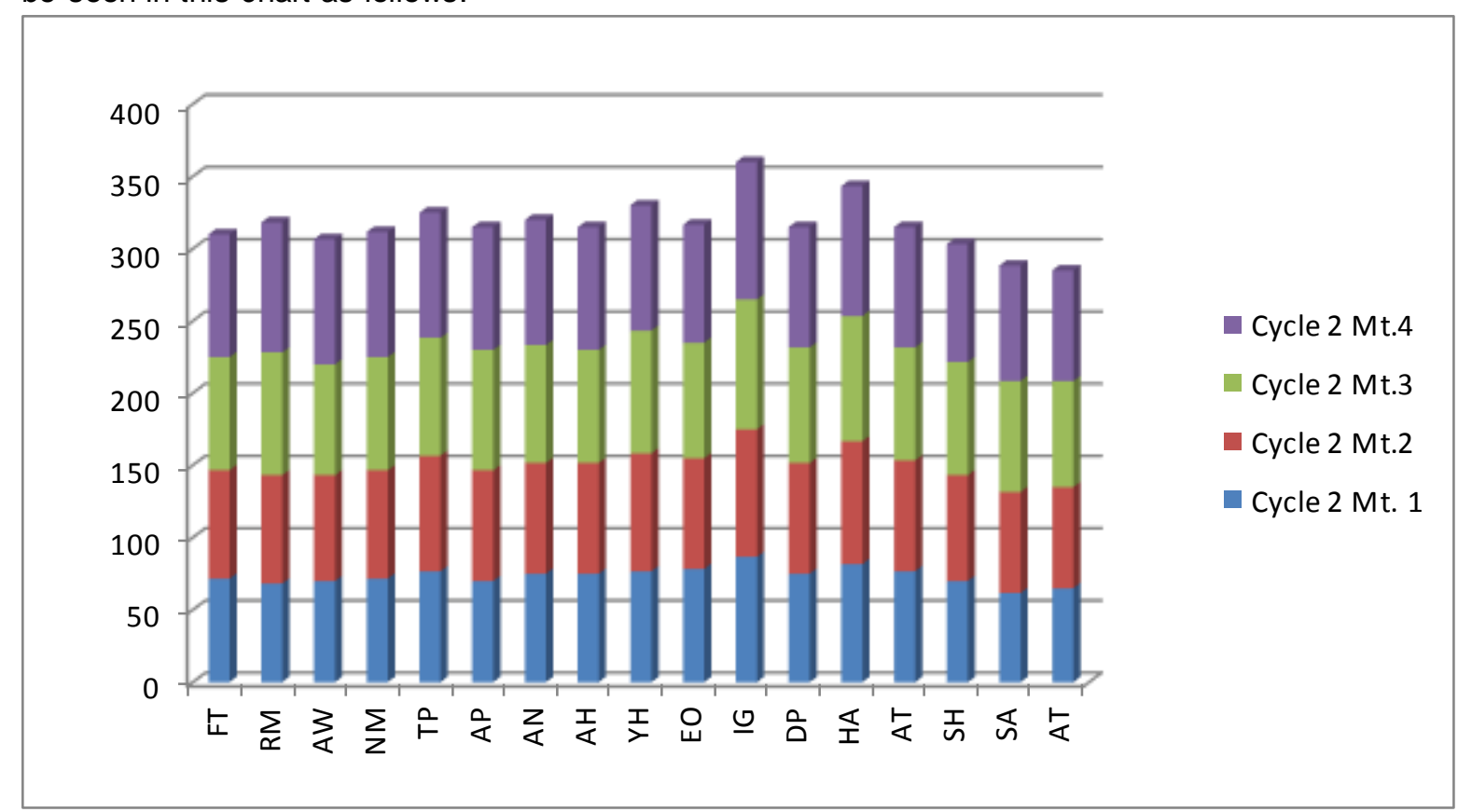

\section{Reflection of Cycle II}

The students could face difficult problems in communicating like managing his fear, embarrassment. Students have begun to have opportunities so they can show how good they are in speaking and sharing ideas. Moreover, they learned to listen to each other points of view and to respect each other ideas and thoughts. Working in pairs also reduced stress and embarrassment. If 
they gave a wrong answer, for example, they would not feel shy because the embarrassment was shared. It created an enjoyable learning environment and increased motivation among learners. Students became more cooperative and able to communicate successfully.

\section{DISCUSSION}

Fishbowl is one of organizing ways of a medium-to large-group discussion that encourages student engagement and can be used to model small-group activities and discussions. Fishbowl takes its name from the way seats are organized with an inner circle and outer circle. Typically, there are three or five seats in the inner circle with the remaining seats or desks forming a larger outer circle, and the rest of the students become the listeners in the outer circle (Osoimanai, 2017).

It is clear; the students had sharp progress when compared to the previous test (pre-test results). On the pre-test, the students got an average score of 46.12 and then the score increased in progress test (speaking test in cycle I) became 64.47. Furthermore, the students' speaking score increased sharply became 80.00. Sungkono (2015) also supported that the Fishbowl technique can improve students' speaking ability.

Therefore, the effectiveness of Inside-Outside Fishbowl brought a significant improvement for the students' speaking achievement. The score of the students had increased well. In other words, there was also an improvement in learning completeness. The learning completeness in cycle I was $29.41 \%$ and cycle II was $94.11 \%$ with the improvement was $64.70 \%$, and it was line with Khadijah (2017), she explained that the implementation of the Fishbowl technique is an effective way to improve students' speaking skill. She also suggested that English teachers or lecturers should use the Fishbowl Technique as a teaching technique to eliminate or overcome some of the problems encountered in speaking classes. This technique is designed to help students to speak about their ideas, to be more active and to be critical and also to help teachers in monitoring and encouraging the students so that they can more easily comprehend the materials

Also, based on the analysis of students' observation in cycle I, the students who had high competence in English dominated the process of discussion. They were active in responding to the moderator's questions. They had tried hard to share their opinion in an inside fishbowl. On the other hand, the students who had low competence in English, they were shy to do all activities. They even seemed to be silent and did not want to perform themselves. If the moderator asked questions, they just followed the dominating one without understanding the real meaning of questions. They were nervous about speaking. They had to try hard to construct even only simple sentences.

After doing the treatment in cycle II, there was a significant improvement in students' vocabulary mastery. More than $80 \%$ of the students were active inactive performing their actions in a discussion session. The students who were not active in the first cycle could give more contribution to the classroom. The prerequisite of learning completeness was if $85 \%$ of the students got to score $\geq 71$ Based on the learning completeness criteria, the means score of the students was 79.76 and learning completeness was $94.11 \%$ in cycle II.

In the implementation of cycle II, all of the students tended to be active in following all the instructions given by the moderator. They were attentive and prompt with the topic discussed they were enthusiasts following activities in the classroom, and they got more confidence to stay in front of the class. Besides, the students' cultural awareness also could be improved by the implementation of the inside-outside fishbowl. The students felt the confidence to speak in the class. It made the students feel free in expressing their idea, willingness, and opinion. This strategy made the students and the atmosphere of the class became alive.

During the implementation of the inside-outside fishbowl to empower students' speaking achievement and cultural awareness, the writers found some positive findings, they are:

(1) There was a positive interaction among students, lecturers, and writers 
(2) The students were more creative and innovative to share their information and opinion through discussion

(3) The students were more enthusiast and active in joining the teaching and learning process

(4) The students got more confidence in speaking in front of many people, they used to speak free based on the valid rules and norms

(5) Cultural awareness was one of the topics or issues which could be raised by the lecturers in university while it could be the basic to improve the young generation's behavior.

(6) With the rise of cultural awareness of the students, they would be more aware of their surroundings and proud of their own country. It would affect their acts to become better in the future.

(7) The lecturers got more solutions in finding more suitable teaching media, materials, and strategies in teaching speaking; they could use inside-outside fishbowl to manage a big class.

(8) The lecturers got more solutions in facing the multi-class group because of their different learning styles, ages, and needs.

(9) The lecturers should aware of the students who had low motivation to speak. They had to encourage those students to become more active in the class.

Moreover, fishbowl discussion is a useful strategy can help students learn the language in a good classroom atmosphere to achieve learning goals. According to Sterling et al (2010), the advantages of fishbowl discussion as follows: 1) Everyone has an equal opportunity to participate. 2) Each participant can have their say without being interrupted. 3) The contributors can freely state their opinions on the subject. 4) It enables the student to become a better listener.

\section{CONCLUSION}

In conclusion, Inside-outside fishbowl could improve speaking achievement and local cultural awareness of the students of Tridinanti University Palembang. Using Inside-Outside Fishbowl (IOF) in EFL classrooms has helped both lecturers and learners in many different ways. It has a positive impact on both of them. Regarding students, IOF application in the classroom has helped them think and organize their thoughts. As a result, they have started to manage their learning and to gain a sense of responsibility. Moreover, they have shown readiness to speak in the target language with more confidence and fluency. These activities have also motivated learners so they have gained a positive attitude toward speaking in a foreign language. Students have begun to have opportunities so they can show how good they are in speaking and sharing ideas.

Based on the results of speaking test and classroom observation that was done in Cycle I and Cycle, it could be concluded that the use of Inside-Outside Fishbowl (IOF) could improve sixthsemester students' speaking ability and the students' understanding of the local culture at Tridinanti University. Considering the results of the research, the researcher proposed some suggestions.

a. It was recommended to the English lecturers, they were suggested to use IOF in teaching speaking to students. It can improve the teaching quality of speaking as the students' speaking ability and the students' active participation during the teaching and learning process of speaking.

b. The students should try to practice speaking using English in the classroom, especially by using IOF to get better scores in speaking ability.

c. Future researchers are suggested to use the research results to conduct further research by using different research.

\section{REFERENCES}

Bahar, K.A. (2013). Communicative competence based on English language teaching. Yogyakarta : Trust Media.

Elizabeth, R. (2005). Learning our vocabulary words while playing fishbow. Retrieved from 
Ridha IIma ${ }^{1}$,and Jenny Elvinna Manurung ${ }^{2}$

www.bio.indiana.edu. Accessed on April 25, 2016.

Grugeon \& Dawes. (2005). Teaching speaking \& listening in primary school. White plains, NY: McGraw Hill, Inc.

Harmer, J. (1991). How to teach English: An introduction to the practice of English language teaching. England: Longman.

Hornby. (1995). How to teach speaking skills. Retrieved from Http://.-toteach-speaking-skill. Html//. Accessed on February 13, 2017.

Khadijah. (2017). Teaching speaking using the fishbowl technique. English Education Jurnal, 8 (2). p. 214.

Kemmis, S., \& McTaggart, M. (1998). The action research planner. Geelong, Victoria: Deakin University.

Kurnia, N. I. (2015). Improving students' spoken recount skills through the fishbowl technique: A classroom action research at the eighth-grade students of SMP N 18 Semarang in the academic year of 2014/2015. (Doctoral dissertation). Semarang, Universitas Negeri Semarang.

Kusmaryanti, S. (2009). Improving speaking achievement through classroom discussion. Jurnal Bahasa dan Seni, 34 (1), p. 234-256.

Liando, N.F.V. (2009). Success in learning English as a foreign language. Litera Jurnal Penelitian Bahasa, Sastra, dan Pengajarannya, 18 (2), p. 146-164.

Linse, T. C. (2006). Practical English language teaching: Young learners. New York: McGraw-Hill.

Nunan, D. (2004). Designing tasks for the communicative classroom. Cambridge: Cambridge University Press.

Mahripah, S. (2013). EFL Learners' attitudes toward the improvement of English speaking performance. Litera Jurnal Penelitian Bahasa, Sastra, dan Pengajarannya, 12 (2), pp. 287299.

Malvin, L. S. (1996). Active learning 101 strategies to teach any subject. Lewiston: Pearson.

Osoimanai, M, \& Hadi, I. (201). Teaching speaking by combining fishbow strategy with debate strategy at senior high school. Retrieved from http://download.portalgaruda.org/article.php. Accessed on October 20, 2017.

Richard, J.C., \& Rodgers, T.S. (2001). Approaches and methods in language teaching. Cambridge: Cambridge University.

Syafa'ah, S. (2010). Improving student's speaking skills through using fishbow technique: A classroom action research with students of $5 b$ at MI Tarbiyatul Banin Pekalongan Winong Pati in the academic year of 2009/2010. (Doctoral dissertation). Semarang, IAIN Walisongo.

Silberman, Mel. (1996). Active learning: 101 strategies to teach any subject. U.K. A Pearson Education Company.

Sungkono, D. (2015). Improving The 7th Grade Students; Speaking Ability Through Fishbow Game at Mts Darur Ridlwan Mumbulsari in the 2014/2015 Academic Year. East Java: University of Muhammadiyah Jember.

Sterling, Shirley., Tohe, Laura. (2010). Workshop 3: research and discovery, teaching strategies, fishbow. Retrieved on June 4, 2017.

Wahyuni, S., Rosdiana, R., \& Fitriani, S. S. (2016). The implementation of the Role Play Technique in improving speaking skills. Proceedings of Consortium of Asia-Pacific Education Universities (CAPEU), pp. 114-120. 